\title{
Loyalty of The Main Character In The Choice Movie Directed By Ross Katz
}

\author{
Unpris Yastanti ${ }^{1}$, Iqbal Hadiyansyah ${ }^{2}$ \\ ${ }^{1}$ Universitas Bina Sarana Informatika \\ e-mail: unpris.uys@bsi.ac.id \\ ${ }^{2}$ Universitas Bina Sarana Informatika \\ e-mail: iqbalhadiyansyah6@gmail.com
}

\begin{abstract}
Cara Sitasi: Yastanti, U., \& Hadiyansyah, I. (2019). Loyality of The Main Character In The Choice Movie Directed By Ross Katz. Wanastra, 11(2), 191-200.
\end{abstract}

\begin{abstract}
The purpose of this analysis is to identify loyalty of the main character, the type of loyalty of the main character, and the moral messages in The Choice movies. The Choice movie is American romantic drama movie directed by Ross Katz and written by Bryan Sipe. This movie based on Nicholas Spark's 2007 novel. This research used descriptive qualitative method to analyze the data. The data are the scenes and the dialogs of the main character that contains loyalty. The results of this research indicates that;(1) The loyalty appears in the main character, Travis Shaw, he explain clearly to be loyalty man in The Choice movie (2) The loyalty types of the main character are romantic loyalist, feeling appears to people who really want something, and loyal sentinel, loyal sentinel is a sense of loyalty where this feeling appears only to the people who closest with them. (3) The moral message contained in the movie is keep loyal and strong, never give up, and always together.
\end{abstract}

Keywords: Literature, Main Character, Types Of Loyalty, The Choice Movie

\section{INTRODUCTION}

Literary work is a work that is formed from an imagination. It is also an expression of the images and events of daily activity directly or indirectly. Literary works have function to entertain or teach something to the readers. The function of this literature can be found in any kind of literary works. As the work of literature has function to entertain and there are many works of literature such as novels, poetry, prose, drama and movie.

Baldick, in Yastanti and Soraya (2016:141) states 'Literature a body of written Worksrelated by subject-matter (e.g. the literature of computing), by language or place of origin (e.g. Russian literature), or by prevailing cultural standards of merit. In this last sense, 'literature' is taken to include oral, dramatic, and broadcast compositions that may not have been published in written form but which have been (or deserve to be)'". Experts argue that literature is a field that is highly regarded for its existence.

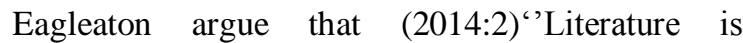
definable not according to whether it is fictional or imaginative." Because literature is a free work of art, therefore literature is imaginative. Furthermore, Pratama argue (2016:49)"Literature is the study of life, humanity, perspective, social, and culture. An appreciation of literature can be enjoyed by many collections of poems, plays, novels, short stories, etc." It can be interpreted that literature is a work in which there is mixing from the perspective of a combination of culture and social and can be enjoyed fromvarious ways through novels, poems, short stories and others that support the literary work itself. So it can be concluded that literature in addition to entertaining and giving the lesson of making it takes time and energy because the literature is the art that comes from experience and something that has emotions in it.

Movie is a complex social, psychological, and aesthetic phenomenon that is a document consisting of stories and pictures accompanied by words and music. So the movie is a multi-dimensional and complex production. The presence of movie in the midst of human life today is increasingly important and equivalent to other media. Its existence is practical, almost equal to the need for food and clothing. It can be said that there is almost no daily life of a cultured man who is untouched by this aspect.

Yastanti and Soraya, states that (2016:33) "Movie is one of entertainment. Many people likes movie, because the message is easy to understand. Through movie people can get some information, entertainment, and education." It means the movie is a medium for entertaining and an entertainment from which can be taken positive messages that are usually contained in a movie. 
According Hornby, (2010:967) express that, "Movie is a series of moving pictures recorded with sound that tells a story, shown on television or at the cinemas or theatre.' Hornby argues that movie is a combination of images or picture and music then combined into an interesting story and aired in theaters.

Forget, (2013;83) states that, "A movie is a collection of shots that are assembled into a sequence that has an identity as a complete work". It means the movie is pieces of images that are strung together to become a whole series and gives the effect that the image is moving that forms a storyline for the movie.

Bazin argues that,(2011:19) "Movie is considered an important art form source of a popular and powerful method for educating." It means movie contain high art and for entertainment and has educated people who watched. The writer assumes that movie is by watching the movie, people can take pleasure and learn the important message about life by which they have not yet known before.

Added by Arfani, (2018:9) states that, "Movie is an art too. The movie was make with rolled into one the art and technology." It can concluded movie can show as an combination of art and technology.

Movies can also have a good vibe for the audience to give a new spirit and suggestions that can generate a the audience and provide the values of life, with the role of actors/artists in the movie, able to influence the attitude of the audience to follow or just do the same. If the movie is loaded with good messages, certainly able to change attitudes and behavior of the audience on the positive way and if the movie contains many negative things then the impact also be felt, it is wise in choosing a movie to watch. Movie teaches people to do positive things then taking the good example and apply in everyday life, and imitate what happens in the movie.

The Choice movie tells of a pair of young people named Travis Shaw (Benjamin Walker) and Gabby Holland (Teresa Palmer) who met in an area in a small coastal town. Travis and Gabby lived side by side until they got to know each other and fell in love with each other. However, on the one hand they already have a partner and must determine who they should choose. The journey of love Travis and Gabby again tested. The long story of their romance is again an event that makes them have to be faced again in a choice, and test the loyal love of both of them in the future.

According to Darmawijaya, (1989:41)express that, "Being loyal is also being firm in the principle." Experts argue that loyalty is also about being faithful to principles, experts have explained that loyalty is not only faithful to a loved one, but can also be faithful to our life principle.

Ladd states that, (1972:97) 'Loyalty is therefore not universal, but concerns a relation with or to particular people." In the other hand loyalty is a relationship with other peoplethus to religion, to the state, and to the promise.Becomes a part of other relations to decide the quality of loyalty.'Loyalty can also take the form of long-term relationships that have been guarded from a long time that gave birth to the quality of real loyalty.

According to Gert, (2013:20) "Without some reasonable expectation of loyalty where loyalty is due, there can be no trust, no friendship, no love." Experts argue that loyalty is a very sincere sense of belonging, without a loyalty there will never be such a thing as loyalty.

Hornby, (2010:256) describe "'Loyalty is quality of being faithful or strong feeling that you want to be loyal. In other definition loyalty also has meaning feeling of duty that is a feeling of devotion, duty, or attachment to somebody or something." It can be said that loyalty is not just a sense of mutual giving but loyalty can also be a sense of loyalty to the state of duty or to someoneyou love.

It can be conclude that loyalty is an important sense of human life in this world, because with loyalty in life, a person will no longer distrust between human beings one and the other.

Here are some ways in which loyalty is expressed in love taken from Darrell, (2017), they are:

1. The romantic loyalist: Diplomats will see loyalty in a more romanticized way. This is less about the standards revered by the Sentinels and more about passion and subjective belief. Loyalty to a life partner might involve being "soul mates" - there may be concern for traditional values or external standards or rules or not. If Diplomat personality types become ignited with a passion for a cause, they will be loyal to that cause and work hard for it. The same with a job if they feel it is purposeful and significant. This loyalty can be a bit shakier than the type enjoyed by the Sentinels. Should these visionaries become disillusioned, all bets are off and loyalty may quickly become a thing of the past. Since they bind their loyalty more to emotions, they may even stand strongly against that to which they were once loyal if disappointed by it. This loyalty leans more toward subjectivity than the Sentinels' variety.

2. The Loyal Sentinel: Sentinel personality types are the most traditionally loyal among all the 
groups. They are fiercely loyal to their families, communities and employers. On top of that, they are faithful to the traditions and values that those who went before them passed along. We know them for their hard-work which relates to their sense of duty which is synonymous with loyalty. The Feeling, especially Turbulent, Sentinels' loyalty is likely a combination of a sense of duty with a heavy dose of emotionality mixed in. They'll see their loyalty as being faithful to others and supporting them. Thinking Sentinels' loyalty is more likely to come from a sense of duty and a need to see things through to a successful end. These personality types, especially Assertive ones, are less likely to involve emotions when they consider their loyalties. They are loyal to the "tried and true".

3. The Conceptual Loyalist This analytical group will be loyal to systems or schools of thought. For example, architects who are also this style of visionary may hold firmly to the theories of a particular school of architecture. They will be "loyal" to those theories. They don't accept others academically or professionally until they have proven themselves. But when these others show they are adept enough, Analyst personalities will embrace them heartily and loyally. When looking for a life partner, analyst personality types may have a checklist, either consciously or subconsciously, of the person they are looking for. When they find their match, they are likely to be loyal to the other person. If this is the most logical partner, according to the features set in advance and sought, then loyalty is a reasonable response. That doesn't mean there aren't feelings involved. But rationality remains the core of any of their alliances. Being loyal is something that "makes sense" to this style of visionary.

4. The Reluctant Loyalists: This is the most difficult of the personality types when it comes to loyalty. This role group is notorious for their novelty-seeking focus. If they are always looking for something "new", that person, place or thing that is "old" will naturally have heavy competition. This dynamic does not bode well when it comes to a discussion of loyalty. While they may not want to stick around on many levels, that doesn't mean there aren't rational or emotional things pulling them to stay. Many Explorers have had long, happy relationships or have remained with causes or institutions for long periods of time. The desire to move on doesn't necessarily govern the many other factors that can convince one to behave loyalty.
Experts explain that loyalty is expression to people who loved ones divided into several parts that exist within each of person that loyalty is one of the most important sense in a relationship that loyalty is one of the most important feeling in a relationship whose presence can be felt through love and that is loyalty.

\section{METHOD OF RESEARCH}

The writers use descriptive method to analyze loyalty of the main characters in The choice movie. The writers find and get some data, and then analyze the data and information by searching internet and library research. In this paper, the writers do some procedures. The writers decide to analyze the movie The Choice as a research material. The writers prepare several theories to support the research. Then the writers watche The Choice movie several times and started analyzing the scenes and conversations needed to be researched. After that, the writers analyze the data. In this section, the writers find the result of the statement of the problem.

\section{FINDING AND RESULT}

\section{The Loyalty in the Main Character}

This movie shows how loyalty of the main character who tries to loyal. It can be seen in some scenes captured below.

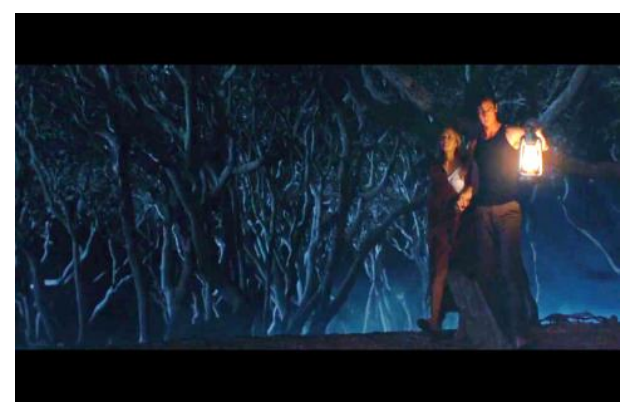

Figure 1 Gabby wants to be loyal to Travis by always being his side.

(On one island under the moonlight, 57:09-1:57:24)

Travis : "There something I want to show you."

Gabby : "Okay." (Both of them went out of the house)

Travis : "All right, so what i'm about to show you, i have never shown anybody. So you can tell a soul, all right?"

Gabby : : Okay." (

Travis : "Welcome to my island."

Gabby : "Your island?"

Travis : "Yeah. My grandfather and I used to come out here and fish. He left it to me when he passed on. This where I come when I want to be alone. And i don't know. I wanted to show it to you."

Gabby : "It's unbelievable." 
Travis : "This is my favorite part. Look." (Travis turned off the lanter that he had brought) from me to you, Gabby. The stars and the moon." (Both of them look towards to the sky)

Gabby : "Let's just stay here forever."

The element of loyalty was again discovered when Travis was so anxious to show something to Gabby, which not everyone knows about his secret place, but to Gabby somehow Travis so wanted to show it, Travis and Gabby are enjoying the beautiful night and moon and starlight thus the star in the sky, where the stars and the moon are the things Gabby love, then Travis turns off the light from which he is carrying, and the moonlight becomes real to make Gabby swear to be there forever.The bold words 'Let's just stay here forever' are the kind of the romantic loyalsit element which illustrates loyal to the life partner like, family, husband / wife, and friends.

In this scene Gabby says that she can not be away from Travis that is implicitly depicting a loyalty.

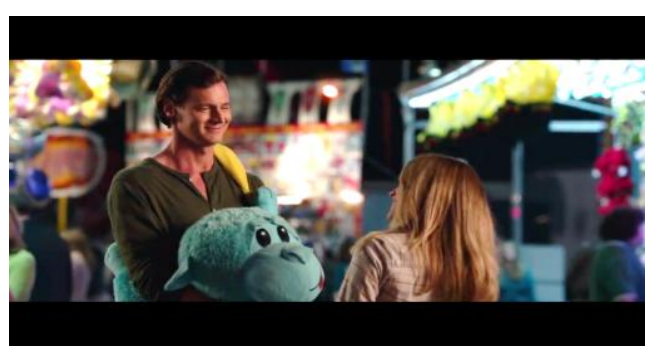

Figure 2. Gabby says can not be away from Travis

(Gabby meet with Travis at a festival, 16:27-17:46)

Travis : "Well, look who it is."

Gabby : 'Wow, can't seem to get away from you.'

Travis : "Yeah. I was going walk on by. But he want to say hello and meet the new doctor."

Gabby : ' 'Well, i'm not technically doctro yet, but it is a pleasure, Mr. Monkey.',

The bold word explain clearly here that implicitly depicting a loyalty with Gabby saying that she can not be far from Travis it can also be said that she always wants to be around Travis and always happy to be near with Travis. Which once again illustrates about the element of loyalty from a friend or severely experts call it a loyal sentinel or they will be loyal to friends, family or work colleagues. That love can actually come from the to realize that the new Travis and Gabby know each other there can feel a sense of love and belonging together when first met.

In a different scene Travis invited by Gabby for dinner,and Travis tell little story about a pair of lovers who used to live in a place that Gabby now live about a loyalty a to old age.

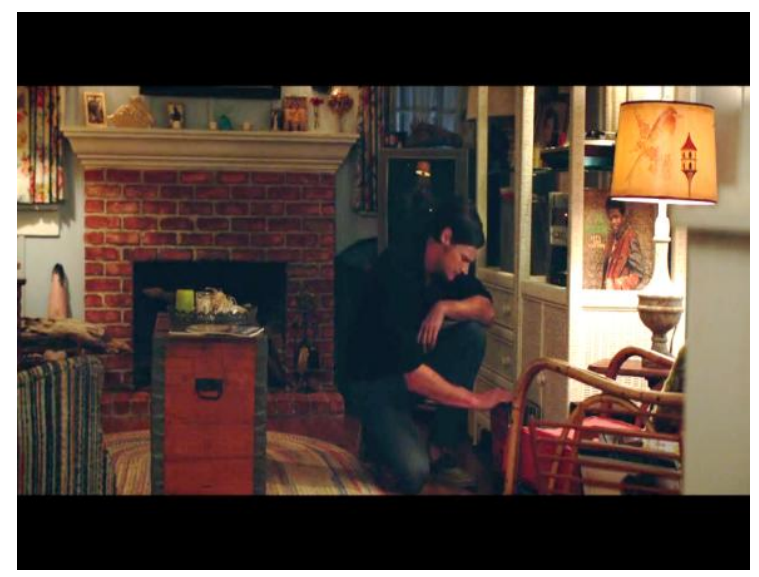

Figure 3. Gabby invited Travis

(In Gabby's house, 40:59-41:33)

Travis : "The couple that used to live here, they used to have music plaiyng all day and all night. You'd see them out in the grass dancing on their anniversary."'

Gabby : ' 'Oh, my God. That is so lovely. What happened to them?',

Travis : ' 'They still around, They just got old and fragile and moved into the home over on cedar and marsh."

Gabby : "'Together?"'

Travis : "'Yeah

Gabby : :'I loove that story."

The bold word clearly illustrates that loyalty is so important to the end of the age and is always at it for a long time with someone who loved. Travis telling anyone who once lived at home who is now Gabby settled, it could indicate that Travis wants to also live the same way story with Gabby.

In different situations Travis proves his loyalty by applying for Gabby in front of both her parents

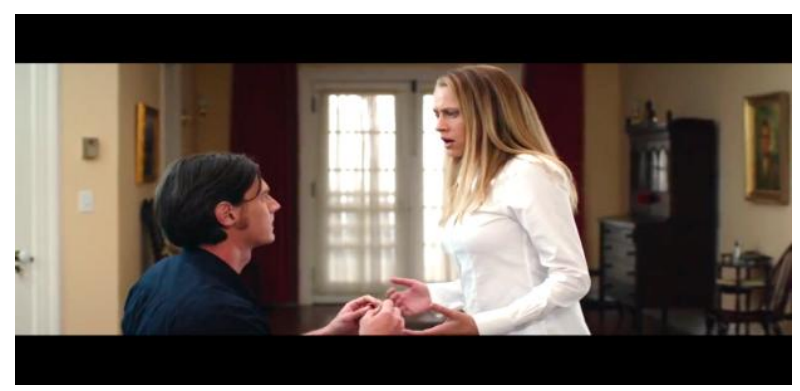

Figure 4. Travis proves his loyalty

(Travis asked her to marry him, 1:13:10-1:13:54)

Travis : ' Gabby, $\mathbf{i}$ think pretty much said all the words. So all i need is a lifetime to prove it to you. Will you marry me? 


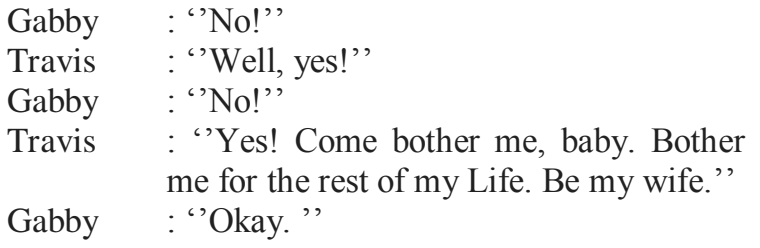

In some scenes Travis proves that he really loves Gabby with a really good way to prove it by for Gabby in front of his mother's father. This clearly illustrates a sense of loyalty. Travis could have been looking for another woman besides Gabby, but he refused it outright and said that he just wanted Gabby to be his wife. It is clear that here comes the element of loyalty, namely romantic loyalist where as mentioned earlier that this element will be loyal to friends, wife/husband or family

In a different scene travis welcomes the return of Gabby gladly that his loyalty awaits there is nothing in vain

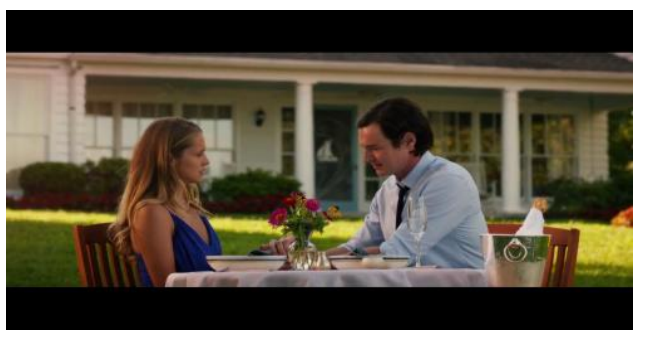

Figure 5. Travis do loyal to Gabby what happened to her

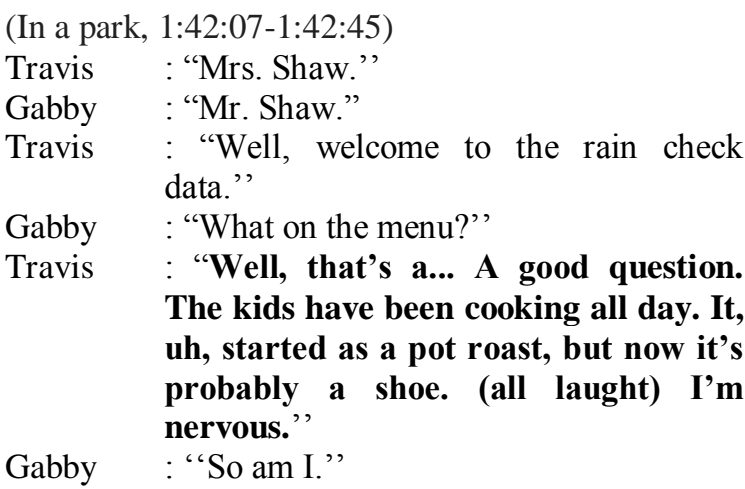

The bold words depicting the happiness of Travis over the return of Gabby into his life again. After accompanying her for about 90 days and Gabby aware of his coma, they finally held a simple celebration of the healthy return of Gabby which was once delayed because Gabby had a coma. It teaches anyone to always be faithful to our couple, whatever happens.

\section{Kind of Loyalty in theMain Character}

After examining several parts in this movie, and find out from a variety of sources and experts who have done prior research, the writer found that there is loyalty that appears in this movie and teaches the value of life as well as the writer found that there are two forms of loyalty very clear and visible in this movie is exemplary also the wirter found that there are two types/kind of loyalty most prominent in The Choice movie they are:

\section{a. The Romantic Loyalist}

According to Darrel,as already discussed in chapter II romantic loyalist is sense loyalty to a life partner might involve being soul mates there may be concern for traditional values or external standards or rules or not. If they personality types become ignited with a passion for a cause, they will be loyal to that cause and work hard for it. The same with a job if they feel it is purposeful and significant.

As in this movie that deeply describes the deep sense of loyalty to the couple and also this movie provides a good example of how a man who is able to be faithful to one partner in this life, whatever happens is always there for his partner and is able to always accompany. This movie as well teaches to always be able to accept any partner she/he has. And by just loving it with a genuinely sincere sense of life can be beautiful again as usual.

In this scene below explains that Gabby worried that Travis could not be loyal to herhe doubts because she just got to know Travis and by that time Travis asked Gabby to be loyal to him.

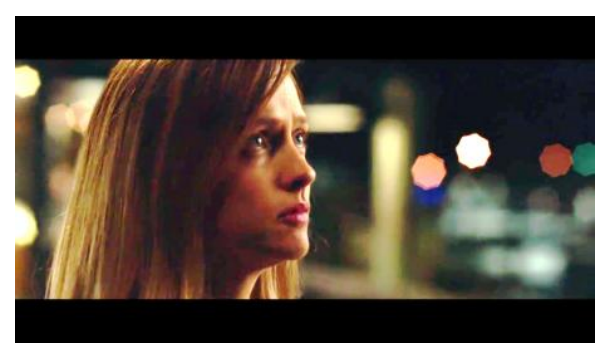

Figure 6. Gabby worried that Travis could not be loyal to her

(In a restaurant near harbour, 1:02:49-1:04:33)

Gabby : 'Not becausse you want to, not because you need it, because you just to win."'

Travis : 'I want you.', (Travis interrupts Gabby)

Gabby : 'We never talked about what this was. It just happened so fast We got caught up."

Travis : 'Caught up? Is taht waht happened? We got caught.',

Gabby : 'We both knew this was cooming around the corner. Neither of Us wanted to acknowledge it.",

Travis : 'All right. All right well, here it is. It's right here, right front of us. So let's acknowledge it. We had an amazing time. 
One of those ground-shaking, lifealltering, knock you on you're ass mouth and I wish could be more. But this is.. This is all I get? So what about you?',

Gabby : ' 'No. No. See, that is not fair. How am I supposed to know how you feel?"'

After passing everything together Travis wants Gabby, but it turns out Gabby is not, because she feels he's still just a friend with Travis and in the next scene Travis proves that he really wants to live with Gabby by saying that he really loves Gabby.

In this scene below explains that Travis is anxious to have Gabby and ask Gabby to stay with him forever.

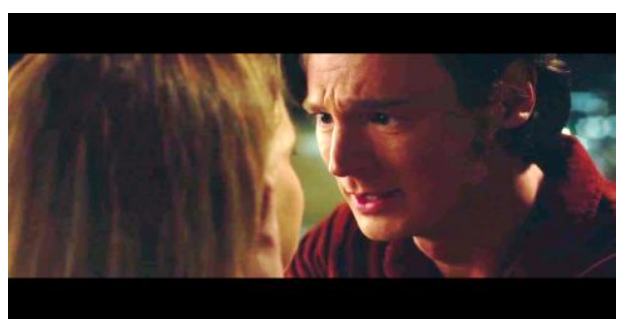

Figure 7. Travis Shaw tells to Gabby what he feel.

(In a restaurant near harbour, 1:02:04-1:03::40)

Travis : 'I love you. You hear me? I love you. I'll say again. I love you. I'll say it a milion times, I love you, I love you , I love you. I knew it the second you walked into my yard ready to rip me a new one hell, my damn dog knew it. Now, do you remember what you said to me on my island, holding my hand under the stars? You said 'Let's stay here forever.'

Well, we can. Me and you. Come home with me, come home, well go in there together and we'll tell them... Together. That is what you want, isn't it? Isn't it?"

Gabby : "I don't know." (Gabby looked confused)

Travis : "All right." (Travis looked disappointed and went slowly disappeared)

The loyalty of the main character is clearly visible here, even though Gabby already has a partner, Travis can not seem to take the Gabby out of the way, because Travis loves Gabby and asks for her promise when under moonlight, there is nothing Travis wants, except always with Gabby. The bold words are sentinel loyal elements which prove to be always loyal at that time Gabby told Travis to stay on his island, but instead now thebold wold illustrates that the character of this is wanted to be loyal to his lover by forcing she to become a lover also Gabby betrayed Travis and he reminded Gabby to return to him.

Also in another scene the romantic loyalist depicts loyalty of Gabby who is waiting for Travis.

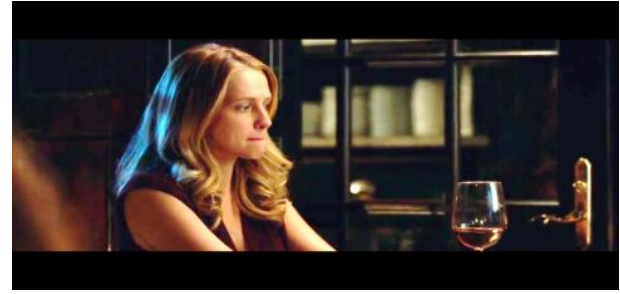

Figure 8. With patience Gabby waiting for Travis appear.

(In a restaurant, 1:1805-1:19:02)

Gabby's Voice : ''Hey, handsome. So the kids finally in the bed and the babysitter arrived earlier, so i'm head out now and just so you know, i'm ordering the most expensive thing on the menu because it's for your treat. I love you. Bye."

In this sectionillustrates that the element of loyalty appears again element of romantic loyalist that loyal to the wife/ husband, friends or family.

In this scene her loyalty is tested, Gabby loves Travis and they make plans for a romantic dinner, but when Gabby has reached in the restaurant first and Travis never comes.Travis on the other hand Travis is still working in theveterinary hospital and he is serving the last customer.Gabby with her loyalty still waiting for Travis and some time Gabby waited until it made her feel as neglected by Travis and in the end Gabby decided to go home because Travis did not come.

On the other hand the loyalty of the main character is highly visible to Travis with his allegiance always bringing flowers to Gabby with his loyalty Travis visiting Gabby in the hospital everyday during Gabby's recovery.

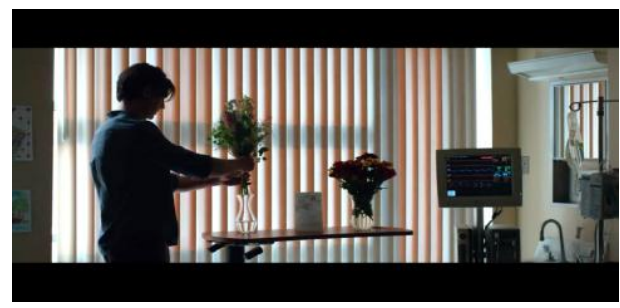

Figure 9. Travis always brought Gabby's favorite flowers.

(At the hospital, 1:22:26-1:22:56)

Travis : "Hey, Babe. Got you some Delphiniums. To be honest, i thoug they were Lilacs but Jackie says they are Dephiniums.I have been putting it of and putting it of. It's like, so much harder than people can even imagine. And everyday's got an opinion on it. But 
since yours the only opinion that I give a damn about, I just wanted to run it past you so here it is."

The bold words explain that the loyalty it is equally important no matter what people are saying about life. Travis also said that if the trials were great and would not be able to imagine by the people. There are so many people's suggestions to abandon the long established relationship, but Travis knows if the reason to survival for the person he really loves, Gabby. So he prefers to be loyal to Gabby, because Gabby is his true love.

In a different scene loyal sentinel was raised when Travis had to wait for Gabby to recover, the image below explains how Travis loyalty is tested because Gabby has been unconscious for several days from her coma.

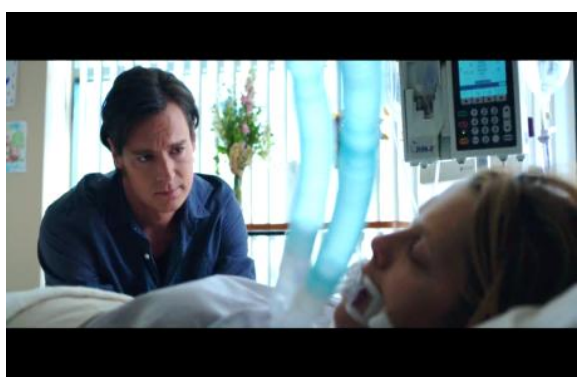

Figure 10. Travis's loyalty was actually tested with Gabby's coma.

(In the hospital, 1:22:20-1:24:47)

Travis : "What i'm gonna do about my pick up tuck. I mean, should I get one of those new hybrids that gells, like 500 miles to the gallon and runs on babies dreams or should I just go ahead and rebuild the tranny in gertrude? Rebuild all right great. That's what I wanted to do anyway. You know, I always had Special place in my heart for fossil fuels. I just hate breathin all that clean air."

The words 'Should I get one of those new hybrids.' is a metaphor of what Travis should try to find a replacement for Gabby, because of the condition Gabby which from day to day more and more worrying, but there are many reasons to start a new thing and Travis consider it. He remain loyal to Gabby because even Gabby like that he is sure one day Gabby will recovered. Very clearly implied with the words 'You know, I always had special place in my heart for fossil fuels.' so travis will always be loyal to Gabby till she come back from her coma. In diffrent scene Travis also wait for Gabby recovery, Travis's loyalty was actually tested with Gabby's coma.

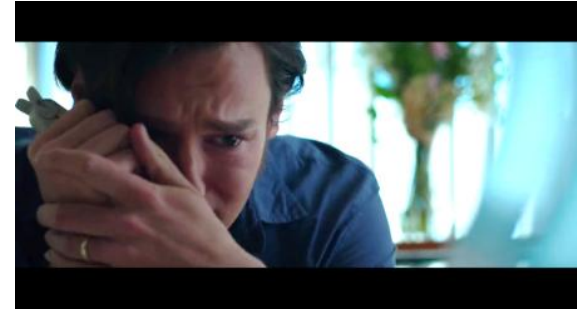

Figure 11. Travis do loyal to Gabby.

(In the hospital, 1:24:03-1:24:47)

Travis : "What going on that head of yours? Come back to me, Baby, we are ruinnin out of time, come bother me."

Once again Travis with his loyalty waiting for Gabby to wake up from her coma. Travis wants the presence of Gabby to tease he as usual, he wants he life back perfect, who knows when Gabby will recover, Travis faithfully awaits the presence of Gabby back, because of the great love he will faithfully await, whatever happened he be there for Gabby . That is love, its presence is precious, its existence is very important, because there is nothing greater in this world than loving with sense of loyalty.

\section{b. The Loyal Sentinel}

Sentinel personality types are the most traditionally loyal among all the groups. They are fiercely loyal to their families, communities and employers. The main character explains that loyalty is a feeling that can appear even through animals and also that dog is a friends of human being.

On this scene below Travis Shaw describe what is loyalty through his loyal dog, Moby.

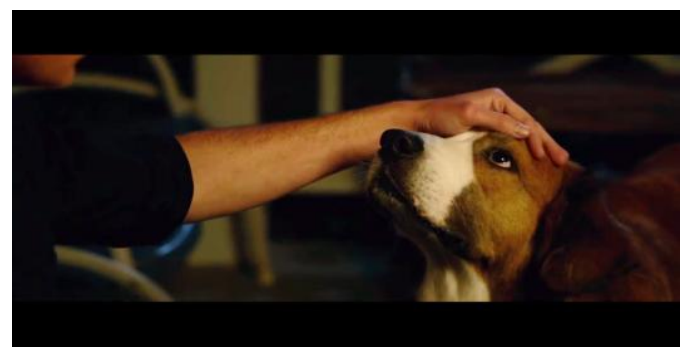

Figure12 Travis explained what is loyalty through his very loyal dog.

(On the porc, 1:38:48-1:39:29)

Gabby : "So you don't believe in god?"

Travis : "Oh, boy"

Gabby : "Oh, boy!"

Travis : "This was going so good."

Gabby : "Oh, boy? Don't 'Oh, boy" on me. An honest question deserves an honest answer."

Travis : "All right, I apologize." 
Gabby : "Okay, so?"

Travis : "You want to know what i'm believe in?"

Gabby :"Yeah."

Travis : "Moby, come here." (Travis called his dog, Moby)

Gabby : "Oh, he has an opinion on this, does he?"

Travis : "Oh, yeah. Watch this. (Travis put his hand on the Moby head, and Moby pushed Travis hand) Now you see that? How he pushesback? He does it every time, and he only does it for me. Now, that's loyalty. I know it sounds stupid, but it's love. Your friends, your family, yourself. That's all you can count in this world and that's what I believe."

Loyalty is discussed when Travis and Gabby are having a leisurely after dinner and they are both seeing a magnificent view outside and ask each other's beliefs and start a conversation that leads to loyalty to a loved one appearing and discussed in this movie very often. The bold wold explains what loyalty is through his dog, it teaches that loyalty or love can come from anywhere it also teaches that there is a sense of faithful in the heart of every creature of God, furthermore loyalty is a feeling of love, it can be in friendship, it can exist in one family, also it is within selves, because loyalty can come from anywhere, even can come from a dog though.

\section{Moral Message}

In every story there must always be a moral message that can take the lesson, as from The Choice movie the writer finds many moral messages in this movie and indeed the moral message conveyed can inspire the audience to be taken good and not taken badly and with a movie that can provide some moral messages in the movie, the audience can easily take the intention of the movie itself whether the message is good or bad. Because nowadays, people selective in choosing movies to watch. And most of the films are always a lot of moral messages, because in addition to giving something to the audience, can also provide some very useful benefits in lifeonce.

In this scene below explaining to be strong with whatever happens in life.The main character also explains that to be a strong there must be someone who supports it.

\section{a. Keep Loyal and Strong}

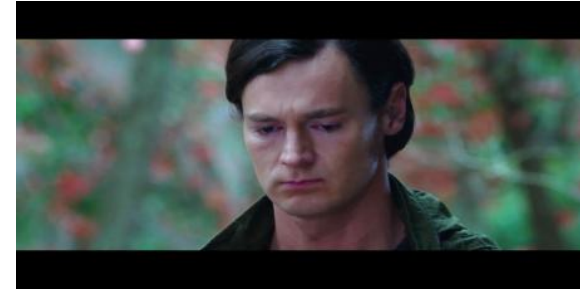

Figure 13. Travis told his sister that he not ready to lose Gabby.

(In the cemetery, 1:26:46-1:31:33)

Travis : " I kept thinking how many times I could've told her I loved her how many times I could've loved her hard oh I had give anything just to be able to tell her just one more time." (Travis spoke to his mother's grave)

Stephanie : "Hey." (Stephanie suddenly appeared) Travis : "Hey."

Stephanie : 'Hi, Mama. (Stephnaie say Hi to her Mother's grave) She's a good listener, hu?"

Travis : 'She's the best. I had make a choice, Steph. Just been so long. Seeing her like that. Knowing it's not what she would want. Hell, she'd be so mad at me. Last night I told her. Today I'd do it, today I would have the strenght. But I Just I just can't do it yet i'm just not ready to let her go."

Even though Travis is trying strongly with whatever happens, he had thought of replacing Gabby with another woman, but he realized that the reason for survival was Gabby the woman he most loved, it is clear here that Travis is very weak and almost giving up in accompanying Gabby with loyalty in her coma, Travis taught to always try to be strong through all that has happened.

In another scene his father gave advice to his son that all this has not done yet. In this scene below Travis's father tried to strengthen Travis that all he had to do was be patient for the moment.

\section{b. Never Give Up}

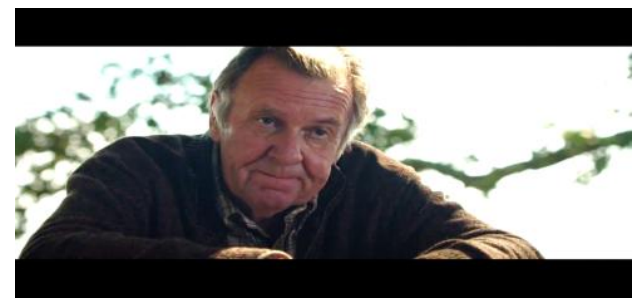

Figure 14. His father advised Travis

(On the veranda of the house after the storm, 1:35:03-1:35:14)

Dr. Shep : "What are you looking for?" 
Travis

: 'Something should be here. I should've been there. If i'd have been on time."

Dr. Shep : "It's not your fault, Travis. Get that of your head. The world breaks everyone, Travis. The very good, the very brave, the very gentle. And those it doesn't breaks, it kills."

Travis : "Is that from the good book pastor, Shaw?"

Dr. Shep : 'Great book. Hemingway. There's no shame in being a broken man. I should know. You just pick up the pieces and start rebuilding."

The word "something should be here" is a metaphor that Travis wants Gabby to be beside him again and went back to his beautiful life but Travis's father encouraged him.

Travis's father gave a very valuable lesson, after a massive storm hit Travis's house. Instead of Travis leaving the city, he wants to stay there to be close to the hospital where Gabby is treated, he does not want to get away from Gabby because if there is any development about Gabby's treatment, Travis wants to be the first person there for her.

He should be thankful to the God because of Travis that he has a father who can support it and provide suggestions that can build mentally Travis that has been destroyed, also Travis's father give a good advice to Travis. His father said there was always a way out when disaster comes do not grieve, because all this has not ended do not easily give up to be a human being, all there must be a way out, believe it is necessary only be patient and all you need to do is just rearrange the destroyed and start repairing and always try to do the best for this life with always never give up even though all kinds of exams are hit in this very difficult life. Because after all when a trials come over try not to give up no matter how difficult life is.

In one picture at the end of this movie explains that if can be faithful to the couple then can through any problem if that loyalty always maintained. In the end of this movie this scene describe what the true loyalty is. After a coma for 90 days and make a romantic dinner that had been planned to fail miserably Gabby and Travis finally came back together.

\section{c. Faithfulness}

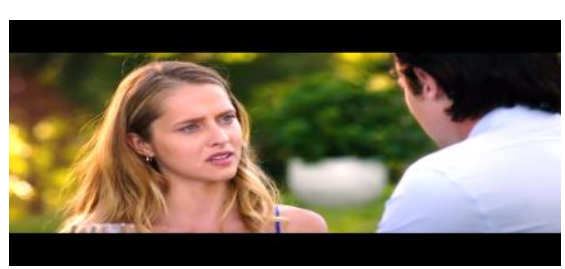

Figure 15 Gabby finally dinner with Travis after coma

(In a park, 1:41:27-1:42:48)

Travis : ' Gabby, I, Uh... I know i've had a lot of time to think about What $\mathrm{i}$ say. If uh.. what i'd say when... and.. u... dang it! I had this all sorted out I did. Now I can't Um...'

Gabby : "Travis, (Gabby interupt) I heard you. I heard... Every word that you said. You Were breathing for me, Baby. Your beat for mine. We got through this together."'

The bold word means being able to always be with anything that will happen to the couple and trust each other, as long as sure the couple will show their loyalty and willing to accept all the weaknesses that exist, and want to both fight for a better life then the beauty of life will soon be obtained because life is a struggle worth fighting for that takes patience and trust, it is already more than a real loyalty,so this movie teaches that in this short life is not just live and gone but there is something that have to build such as relationship with someone and admire that loyalty is very important in this life that can only with loyalty. Love can growthand also teaches to be loyal to the partner to make relationship feel better. That enjoyment and distress is a part of life too and it will be very beautiful if someone who supports to always be better.

In the context of love loyalty is very important because without it there will be no true love stories like Romeo and Juliet, without loyalty love is nothing because true love is a sense of mutual loyalty. Also the scene gives a lesson, that to love someone does not need to love it with something luxurious and expensive, because it is enough with a simple way to love and sincere love can grow easily among humans, because nothing is greater than this world than loyalty.

\section{CONCLUSION}

The result of the research shows that a great sense of loyalty of main character to his partner, making the loyalty interesting to be examined in this movie. The main character in this movie explain the loyalty that is very important feeling in this short life especially for life in lovers, because only with that feeling can make a truly human whole, the unyielding human beings, become human who can be relied upon by a couple and become a loving human being. Travis Shaw was really tried in loyalty when his beloved Gabby Holland was in a coma for 90 days and during that time there was not the slightest heart Travis wanted to turn from Gabby. Also the only 
woman who would accept Travis as he was. Although Travis had thought of leaving Gabby with after what had happened but the reason for leaving Gabby was not too big when compared with his loyalty.

Kind loyalty of the main character show as when Travis patiently waiting for his lover Gabby to wake up recovered from a coma, there is an element of loyal sentinel in the main character of this movie, loyal sentinel is a sense of loyalty where this feeling appears only to the people who closest with them.Travis love as big as the world to Gabby could not possibly leave Gabyy because Travis very well remember that one the only reason he still survives with this condition is his own sweetheart, Gabby. Here also appears the feeling of the main character in this movie that features a sense of loyalty named romantic loyalist where this feeling appears to people who really want something it the same with Travis when askedGabby as his wife.

Certainly in a movie there will always be a moral message to be conveyed clearly, and in this movie the main character explains very clearly, that to be a more patient person and loyalty what ever happened and when feel the weakest point in life is needed just one thing, start spirits again and start from the beginning. This movie gives a lot of lesson that loving someone does not need to use expensive things, to love someone with sincere need only one thing that every human should have, a sense that should every creature have, feelings capable of making love ends beautifully, that is loyalty.Unfortunately not only to others, but to the universe and its contents and able to become a better person in maintaining the commitment, especially in a relationship capable of being a human that can be trusted, can be a reliable human and most important of all this is able to be a man of great with loyalty.

\section{BIBLIOGRAPHY}

Arfani, S. and S. (2018). The Schizoprenia in The Main Character of A Beautiful Mind Movie Directed By Ron Howard. Journal Wanastra ABA BSI Jakarta. VOL X NO.1 9-16 Retrieve http/ejournal.bsi.ac.id/ejournal/index.php/wan astra/article/vie/2648/206 ed from. VOL X NO.1.

Baldick. (2016). Baldick, in Yastanti Unpris. (2016) Imagery Analysis In William Shakespeare's Sonnets Wasastra ABA BSI Jakarta. Vol.VIII No. $01 \quad$ maret http/ejournal.bsi.ac.id/ejournal/index.php/wan astra/article/vie/2648/206. Vol.VIII N. from source of popular. Oxfor: Oxford paperback.

Darmawijaya, D. (1989). Kesetiaan merupakan suatu tantangan Yogyakarta. 1989.

Darrell. (2017). Types of loyalty and types of people.

Eagleaton, T. (2014). Revised edition theory of an intoduction language Roman Jacobson. Ordinary language.

Forget, T. (2013). The Contructiton of Drawing and Movies. New York: Routledge.

Gert, B. (2013). Loyalty and Morality New York: New York University Press. New York: New York University Press.

Hornby, A. . (2010a). Oxford Advanced Learner's Dictionary. New York Universidt Press.

Hornby, A. . (2010b). Oxford Advanced Learner's Dictionary. New York University Press. New York University Press.

Ladd, J. (1972). The Encyclopedia of Philosophy. Reprint Edition. Volume 5. Londen: Collier MacMillan publishers. London: Collier MacMillan publishers.

Pratama, R. M. D. (n.d.). Dissociative Identity Disorder of Main Character in Sybil Novel by Flora R. S Based on Psychological Perspective. Journal Progressive Nusa Mandiri Jakarta. Vol XI No.1. 49- 58. Retrieved from http://ejournal.nusamandiri. 2016.

Yastanti, U. and E. S. (2016). Schizophrenia Of Main Character In Beautiful Mind Movie Directed By Ron Howard. Journal ABA BSI Jakarta. Vol. 8 No. 1 33-45. Retrieved from http://ejournal.bsi.ac.id/ejurnal/index.php/wan astra/article/view/1251/101 6. Vol. 8 No.

Yastanti, U., \& Hadiyansyah, I. (2019). Loyality of The Main Character In The Choice Movie Directed By Ross Katz. Wanastra, 11(2), 191200.

Bazin. (2011). Movie considers as important art 